\title{
A STUDY ON DETERMINATION OF BIOACTIVE POTENTIALS OF CERTAIN LICHENS
}

\author{
A.I. KorkmaZ ${ }^{\mathrm{a}}$, H. Akgul ${ }^{\mathrm{a}}$, M. SevindiK ${ }^{\mathrm{a}}$ and Z. Selamoglu ${ }^{\mathrm{b} *}$ \\ ${ }^{a}$ Department of Biology, Faculty of Science, Akdeniz University, Antalya. Turkey \\ ${ }^{b}$ Department of Medical Biology, Faculty of Medicine, Nigde Ömer Halisdemir University, Nigde. Turkey
}

(Received: 22 March 2017; accepted: 15 June 2017)

Lichens are symbiotic associations that are formed by fungi and algae or cyanobacteria. The number of lichen
species investigated pharmaceutically is still very low at present. The present study aims to determine the antioxidant
activities, antibacterial activities, DNA protective activities, and oxidative stress status of Bryoria fuscescens
(Gyeln.) Brodo \& D. Hawksw., Parmelina tiliacea (Hoffm.) Hale, and Umbilicaria decussata (Vill.) Zahlbr. Lichens
were extracted with ethanol in the Soxhlet device. The DPPH method was used to determine antioxidant activities.
DNA protective activity was determined using pBR322 supercoil DNA. Antibacterial activity was determined with
dilution test on 5 different species of bacteria (Enterocossus faecalis, Klebsiella pneumoniae, Pseudomonas
aeruginosa, Escherichia coli, and Staphylococcus aureus). Total antioxidant status (TAS), total oxidant status
(TOS), and oxidative stress index (OSI) were defined with Rel Assay Diagnostics kits. It was observed that DPPH
free radical scavenging activities in lichen ethanol extracts increased with increasing concentration. The highest
antioxidant activity was observed in B. fuscescens and the lowest activity was determined in U. decussata. It was
also determined that the ethanol extracts of all lichen samples had DNA-protective activity. The highest antibacterial
activity was detected in B. fuscescens, while the lowest activity was detected in U. decussata. It was determined that
B. fuscescens had the highest oxidative stress index and $U$. decussata had the lowest value. It appears that the ethanol
extracts of the lichen samples utilized in the study could be used as an alternative and complementary resource in
medical treatment.
Keywords: Bryoria fuscescens, Parmelina tiliacea, Umbilicaria decussata, biological activity, oxidative stress

Lichens are symbiotic associations of fungi and photosynthetic living organism groups (green algae and/or cyanobacteria) (THADHANI et al., 2011). There is today a growing interest in new bioactive natural products for the prevention and treatment of various diseases (MoRIANo et al., 2015). Lichens produce secondary metabolites such as depsides, depsidones, quinones, xanthones, dibenzofuran, diketopiperazine, and pulvinic acid (STUDZIŃSKA-SROKA et al., 2016). Among the lichen species we used in our study, Bryoria fuscescens contains fumaroprotocetraric acid, atranorin, and psoromic acids. In addition, Bryoria species are characterized by the presence of norstictic, alectoralic, barbatolic, and gyrophoric acids (Velmala et al., 2014). Parmelina tiliacea is mostly known for its presence of atranorin and lecanoric acids. In addition, they contain salazinic, norstictic, and protocetraric acids (Cernajova and Svoboda, 2014). Umbilicaria decussata contains norstictic, ovoic, and gyrophoric acids. Umbilicaria species are also known to contain lecanoric, hiascic, umbilicaric, and salazinic acids (SeriÑa et al., 1996; Zlatanović et al., 2017). Lichens are rich sources of active substances with various biological activities, such as antibiotic, antifungal, antiviral, anti-inflammatory, analgesic, antipyretic, antimutagenic, anti-

* To whom correspondence should be addressed.

Phone: +90-388-2253123; fax: +90-388-2252582; e-mail: zselamoglu@ohu.edu.tr 
proliferative, antitumor, antiallergenic, and cytotoxic effects, due to the secondary metabolites they contain (BRISDELLI et al., 2013; Sisodia et al., 2013). Thus, the determination of potential bioactivities of lichens is significant for the determination of their use as an alternative natural and conservative resource.

Oxidative compounds that cause oxidative stress could also cause several pathological formations, such as atherosclerosis and cancer along with aging as a result of cellular and tissue damage (PAUdel et al., 2008). Various antioxidant sources, including antioxidant enzymes, food, and medicine, play important roles in the prevention of cellular degeneration to reduce oxidative damage (Luo et al., 2010). In addition to these antioxidant agents, it is important to examine lichens in terms of antioxidant activity and oxidative stress index (OSI).

Due to erratic use of synthetic medicines and consequently increasing resistance of microorganisms to existing antibiotics, researchers have turned to new natural resources to control and prevent various human, animal, and plant diseases (RANKOVIC et al., 2011). In addition to the identification of antioxidant potentials of lichens that are considered among these natural sources, determination of their antimicrobial potential would benefit the identification of bioactivities of natural resources.

There is very little information about the biological activities of Bryoria fuscescens (Gyeln.) Brodo and D. Hawksw, Parmelina tiliacea (Hoffm.) Hale, and Umbilicaria decussata (Vill.) Zahlbr lichens used in the study. In the present study, new natural and protective agents were identified, antioxidant, antibacterial, and DNA protective activities of $B$. fuscescens, $P$. tiliacea, and $U$. decussata were determined. It was also aimed to reveal the oxidative stress indices, demonstrating the antioxidant potential of these lichens against oxidants.

\section{Materials and methods}

\subsection{Collection and extraction of lichen samples}

Bryoria fuscescens (Gyeln.) Brodo \& D. Hawksw lichen species tested in the study was collected from Abies sp. in Çat forest in Sivas province at $1580 \mathrm{~m}$, Parmelina tiliacea (Hoffm.) Hale species was collected from Pinus brutia in Yaraş village in Muğla province at $750 \mathrm{~m}$, and Umbilicaria decussata (Vill.) Zahlbr. was collected from volcanic rocks on Erciyes Mountain in Kayseri province at $2800 \mathrm{~m}$.

The collected homogeneous lichen materials were dried at room temperature in the laboratory, cleaned and homogenized with the help of a mechanical grinder. Then, 30 grams of the powdered lichen were placed in cartridges, and ethanol extraction was performed at $75{ }^{\circ} \mathrm{C}$ for about 6 hours in the Soxhlet device (Gerhardt EV 14). The obtained extracts were concentrated under pressure in a rotary evaporator (Heidolph Laborota 4000 Rotary Evaporator). These extracts were filtered using Whatman filter paper and stored at $+4{ }^{\circ} \mathrm{C}$ until the experiment.

\subsection{Determination of antioxidant activities}

DPPH free radical scavenging activities of ethanol extracts of lichen samples were determined (Shimada et al., 1992). Six samples from the same lichen species were analysed in three replications. 1,1-diphenyl-2-picrylhydrazyl (DPPH) (Sigma, Aldrich) is a stable free radical with maximum optical absorbance at $517 \mathrm{~nm}$ (SUBBA RAO et al., 2010). The DPPH reaction 
and the free radical scavenger mixture cause a decrease in absorbance value at $517 \mathrm{~nm}$. Stock solutions containing $1 \mathrm{mg} \mathrm{m}^{-1}$ lichen sample were prepared in DMSO. Fifty microlitres of the solution was reacted with $160 \mu 10.039 \%$ DPPH. It was incubated for 30 minutes in a dark environment at room temperature. Absorbance values were then obtained at $517 \mathrm{~nm}$ in a spectrophotometer. Procedures were repeated separately for all concentrations and samples. As a reference antioxidant, ascorbic acid was used. Then DPPH free radical scavenging fractions were calculated with the following formula:

$$
\text { Scavenging activity }=\left[\left(\mathrm{A}_{\mathrm{DPPH}}-\mathrm{A}_{\text {Sample }}\right) /\left(\mathrm{A}_{\mathrm{DPPH}}\right)\right] \times 100 \text {. }
$$

\subsection{Determination of antibacterial activities}

The antibacterial activities of the lichens were tested on Enterococcus faecalis 29213, Klebsiella pneumoniae 700603, Pseudomonas aeruginosa 27853, Escherichia coli 35218, and Staphylococcus aureus 28213 bacteria.

Seventy-two milligrams of each sample was weighed and $1 \mathrm{ml}$ of distilled water was added to prepare stock solutions of $72 \mathrm{mg} \mathrm{ml}^{-1}$. One hundred millilitres of MHB (Mueller Hinton Broth) liquid medium was added to the plate wells and $100 \mu \mathrm{l}$ of the prepared samples were added to the first well of each line. One hundred millilitres was taken from the first well, transferred to the 2 nd well, and diluted by applying the same procedure up to the $12^{\text {th }}$ well. After pipetting from the last well, $100 \mu \mathrm{l}$ of sample was taken and discarded. Finally, a $100 \mu \mathrm{l}$ $0.5 \mathrm{McF}$ arland bacterial sample (after the measurement was performed) was added to all wells. The samples were incubated at $37^{\circ} \mathrm{C}$ for $24 \mathrm{~h}$. After the incubation, the samples were measured and the minimum inhibitory concentration (MIC) of the lichens was calculated. [Bacterial calibration was done by dilution in physiological serum and measuring in McFarland (Biomerieux) instrument.]

\subsection{Determination of DNA protective activities}

Plasmid pBR322 (Vivantis) was used for the detection of the activities of ethanol lichen extracts for the protection of DNA from UV and oxidation induced damages. Plasmid DNA was damaged in the presence of lichen extracts by exposure to $\mathrm{H}_{2} \mathrm{O}_{2}$ and UV, and imaging was performed on a $1.5 \%$ agarose gel (RUSSO et al., 2000). In order to prepare 5\% stock

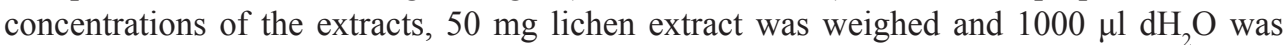

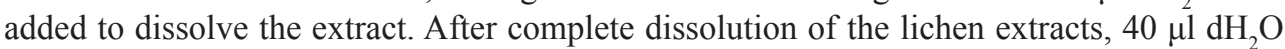
was added to $10 \mu \mathrm{l}$ of the extract of the $5 \%$ lichen extract solution to dilute it to $1 / 5$ of the volume, and this ratio was used in the study (TEPE et al., 2011).

Five microlitres of lichen extract was added to the tubes except those in the control group, and $3 \mu \mathrm{l}$ pBR322 plasmid DNA and $1 \mu \mathrm{l} 30 \% \mathrm{H}_{2} \mathrm{O}_{2}$ were added. Tubes with lichen extracts were exposed to UV rays for 5 min with the tubes 4 and 5. Then, $2 \mu l$ load buffer was added and they were loaded to $1.5 \%$ agarose gel. An UV translucent (DNR-IS) instrument with a wavelength of $302 \mathrm{~nm}$ and a density of $8000 \mu \mathrm{W} \mathrm{cm} \mathrm{cm}^{-1}$ at room temperature was used as light source. The present study, where pBR322 plasmid DNA was used as a control, was imaged in a gel documentation system (DNR-IS, MiniBIS Pro) after 1.5\% agarose gel electrophoresis application. 


\subsection{Determination of TAS, TOS, and OSI values}

Total antioxidant levels (TAS) and total oxidant levels (TOS) of lichen extracts were measured using Rel Assay brand commercial kit (Rel Assay Kit Diagnostics, Turkey) (EReL, 2004, 2005). Analyses were performed with six samples from the same lichen species in 5 replicates. Trolox, a water-soluble analogue of vitamin E, was used as a calibrator for TAS values. The results are expressed in mmol Trolox equiv./l. Hydrogen peroxide was used as calibrator for TOS values. The results are expressed as $\mu$ mol $\mathrm{H}_{2} \mathrm{O}_{2}$ equiv./l. The oxidative stress index (OSI), expressed as a percentage of the ratio of TOS levels to TAS levels, was calculated using the following formula:

$$
\text { OSI }=\frac{\text { TOS, } \mu \mathrm{mol} \mathrm{H}_{2} \mathrm{O}_{2} \text { (equiv./l) }}{\text { TAS, mmol Trolox equiv. } / 1 \times 10}
$$

\subsection{Statistical analysis}

Standard error values of DPPH analysis and oxidative stress parameters (TAS and TOS) were determined using Microsoft Excel (2010).

\section{Results and discussion}

\subsection{DPPH free radical scavenging activities}

DPPH free radical scavenging activity $\%$ inhibition \pm Std values for the ethanol extracts of $B$. fuscescens, P. tiliacea, and U. decussata are presented in Table 1.

Table 1. DPPH free radical scavenging activity values for lichen extracts ( $\%$ inhibition \pm Std)

\begin{tabular}{lcccc}
\hline \multirow{2}{*}{ Concentration $\left(\mathrm{mg} \mathrm{ml}^{-1}\right)$} & B. fuscescens & P. tiliacea & U. decussata & Ascorbic acid \\
\cline { 2 - 5 } & \multicolumn{5}{c}{$(\% \pm$ Std $)$} \\
\hline 0.5 & $70.21 \pm 4.64$ & $47.25 \pm 1.77$ & $35.95 \pm 1.67$ & $92.52 \pm 0.96$ \\
1 & $78.16 \pm 6.94$ & $56.36 \pm 3.50$ & $44.85 \pm 1.44$ & $95.42 \pm 1.03$ \\
\hline
\end{tabular}

Values are presented as mean \pm Std.; $n=6$ (experiments were made in 3 parallels)

An increase in the DPPH free radical scavenging activity of lichen ethanol extracts was observed with the increase in the extract concentration. The highest activity was observed in B. fuscescens, while the lowest activity was observed in U. decussata.

In a study, conducted on antioxidant activities of lichens, the \% inhibition value for the DPPH Free Radical Scavenger Activity of Umbilicaria cylindrica was 34.45 for methanol extract and 31.34 for chloroform extract (MANOJLOvic et al., 2012). In another study, the \% inhibition value for methanol extract of Umbilicaria decussata was reported to be 23.36 (Bucukoglu et al., 2013). Furthermore, the inhibition value of acetone extract of Umbilicaria crustulosa was reported to be $88.7 \%$ (ZLATANOvić et al., 2017). It was also reported that Bryoria fuscescens had antioxidant activity as well (ODABASOGLU et al., 2005). In the present study, we utilized B. fuscescens, P. tiliacea, and U. decussata lichens, and found that the 
DPPH free radical scavenging activities of ethanol extracts were different from those reported in the literature. It is believed that this difference might be due to the different types of lichen species and solvents used. It was concluded that the lichen species tested in our study might be used as an effective antioxidant source.

\subsection{Antibacterial activities}

MIC values of lichen extracts were determined, and the findings are presented in Table 2.

Table 2. Antibacterial activities of lichen extracts

\begin{tabular}{lccc}
\hline Microorganisms & \multicolumn{2}{c}{ MIC: Minimum inhibitor concentration $\left(\mu \mathrm{g} \mathrm{ml}^{-1}\right)$} \\
\cline { 2 - 4 } & B. fuscescens & P. tiliacea & U. decussata \\
\hline E. faecalis & 3 & 12 & 12 \\
K. pneumoniae & 6 & 12 & 6 \\
P. aeruginosa & 0.75 & 0.75 & 0.75 \\
E. coli & 0.75 & 0.01 & 3 \\
S. aureus & 3 & 6 & 6 \\
\hline
\end{tabular}

The lichen extracts tested demonstrated broad spectrum of antibacterial activity against the bacterial species used in the study. It could be argued that $B$. fuscescens ethanol extract was generally more effective against bacteria used in antibacterial tests. On the other hand, $P$. tiliacea ethanol extract was found to have higher activity against E. coli bacteria when compared to other lichen samples. The lowest activity was demonstrated by the U. decussata ethanol extract.

In certain studies conducted on antibacterial activities of lichens, it was reported that acetone and methanol extracts of Umbilicaria crustulosa and acetone and ethanol extracts of Umbilicaria polyphylla exhibited antibacterial activity (RANKOVIC et al., 2007, 2009). It has also been reported in a study that methanol and ethyl acetate extracts of Umbilicaria cylindrica exhibited antibacterial activity (MANOJLOVIC et al., 2012). In our study, it was determined that ethanol extracts of $B$. fuscescens, $P$. tiliacea, and $U$. decussata demonstrated antibacterial effects against the tested bacteria, and the obtained results were consistent with the results reported in the literature. Especially, it was observed that ethanol extracts of lichens tested against $P$. aeruginosa and $E$. coli bacteria were more effective, and significant protective effects against these bacteria were demonstrated. The present study identified that ethanol extracts of the lichens tested for antibacterial effects could be used as natural protective agents against bacteria utilized in the study.

\subsection{DNA protective activities}

The DNA protective activities of ethanol extracts obtained from B. fuscescens, $P$. tiliacea, and $U$. decussata lichens were tested using pBR322 plasmid DNA and the findings are presented in Figure 1. 


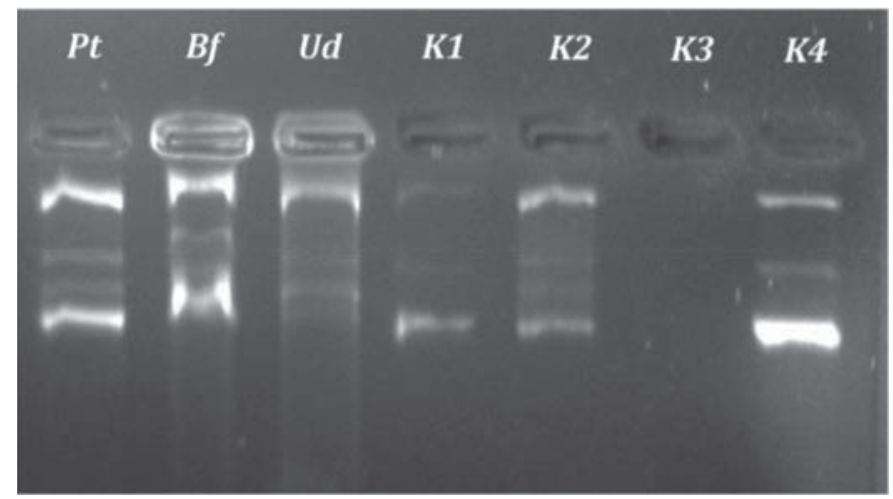

Fig. 1. The electrophoretic gel image with $0.005 \mathrm{mg} \mu \mathrm{l}^{-1}$ concentration lichen samples after $\mathrm{UV}$ and $\mathrm{H}_{2} \mathrm{O}_{2}$ treatment of pBR322 plasmid DNA. $\left(1^{\text {st }}\right.$ well: P. tiliacea, $2^{\text {nd }}$ well B. fuscescens, $3^{\text {rd }}$ well: $U$. decussata, $4^{\text {th }}, 5^{\text {th }}$, $6^{\text {th }}$, and $7^{\text {th }}$ wells: control group [Plasmid DNA, plasmid DNA $+\mathrm{UV}$, plasmid DNA $+\mathrm{UV}+\mathrm{H}_{2} \mathrm{O}_{2}$, plasmid DNA + $\mathrm{H}_{2} \mathrm{O}_{2}$, respectively])

In agarose gel electrophoresis, pBR322 plasmid DNA forms rapid-travelling supercoiled DNA (scDNA), which is the natural form of plasmid, and slow-travelling open-circular DNA (ocDNA) bands. As a result of the exposure of scDNA to UV light in the presence of $\mathrm{H}_{2} \mathrm{O}_{2}$, DNA breaks to form linear DNA (linDNA) (TEPE et al., 2011). As shown in Figure 1, ethanol extracts of all lichens at concentrations of $0.005 \mathrm{mg} \mathrm{\mu l}^{-1}$ provide significant protection against ocDNA, linDNA, and scDNA damage. The ethanol extracts of $P$. tiliacea, showing clearer and glossed DNA bands on the agarose gel, were found to provide better protection against DNA damage than the other lichen extracts.

\subsection{TAS, TOS, and OSI values}

TAS, TOS, and OSI values of lichen extracts were determined using "Rel Assay Diagnostic" kits and the findings are shown in Table 3.

Table 3. TAS, TOS, and OSI values of lichen extracts

\begin{tabular}{|c|c|c|c|}
\hline & $\begin{array}{l}\text { TAS (mmol Trolox } \\
\text { equiv./l) } \pm \text { Std }\end{array}$ & $\begin{array}{c}\mathrm{TOS}\left(\mu \mathrm{mol} \mathrm{H}_{2} \mathrm{O}_{2} \text { equiv./l }\right) \\
\pm \mathrm{Std}\end{array}$ & $\begin{array}{c}\text { OSI }(\text { TOS } / \text { TAS } \times 10) \\
\pm \text { Std }\end{array}$ \\
\hline B. fuscescens & $3.93 \pm 0.45$ & $22.81 \pm 2.11$ & $0.58 \pm 0.013$ \\
\hline P. tiliacea & $4.07 \pm 0.33$ & $14.68 \pm 1.64$ & $0.36 \pm 0.010$ \\
\hline$U$ U. decussata & $3.67 \pm 0.18$ & $8.84 \pm 0.32$ & $0.24 \pm 0.001$ \\
\hline
\end{tabular}

TAS: Total antioxidant status; TOS: total oxidant status; OSI: oxidative stress index

Values are presented as mean \pm Std; $n=6$ (Experiments were made in 5 parallels)

The highest TAS value was observed in P. tiliacea, the lowest value was observed in $U$. decussata. The highest TOS value was found in B. fuscescens and the lowest value was found in $U$. decussata. The oxidative stress index, which indicates the level the oxidant factors that emerge due to environmental and structural effects, affecting the antioxidant system, was the lowest in $U$. decussata, and the highest in B. fuscescens (Table 3). 
The increase in the concentration of reactive oxygen species in the living organism could lead to molecular DNA damage, cellular disorder, and consequently to several pathological effects, cancer in particular and various chronic diseases (HUI-YIN et al., 2001). Water extract of the lichen collected in Erzurum and Artvin provinces had a TAS value of $8.23 \mathrm{mmol}$ Trolox equiv./1, and a TOS value of $11.21 \mu \mathrm{mol}_{2} \mathrm{O}_{2}$ equiv./1 (Aydin and TuRKEZ, 2011). Based on these results, OSI data for B. capillaris was determined as 0.14 . Taking these findings into consideration, OSI values of lichens were found to be higher in our study. Erzurum and Artvin provinces, where Bryoria capillaris was collected, were noted to be more suitable environments for lichens based on oxidants when compared to Sivas, where $B$. fuscescens was collected, Kayseri, where $U$. decussata was collected, and Muğla, where $P$. tiliacea was collected. In addition to all these factors, differences between localities where lichens were collected, utilized solvents, and lichen species are considered factors leading to different results.

\section{Conclusions}

Based on the collected data, it was found that B. fuscescens, P. tiliacea, and U. decussata were potent natural antioxidant resources due to their DPPH free radical scavenging activities. It can also be emphasized based on this study that these lichen specimens could be consumed as natural inhibitor agents against the proliferation of pathogenic bacteria and some of the disorder these might cause. Oxidative stress indices of lichen samples obtained from the abovementioned regions, due to their total oxidant levels, were found to be also high. It may be advisable to consume these species as a natural source of antioxidants, particularly from regions that are less exposed to oxidant agents, with a warning of controlled use of lichen samples collected from the abovementioned regions.

The provision of suitable preparations of lichens with different characteristics of bioactivity as a pharmacological agent could be utilized as an effective antioxidant, antimicrobial, and DNA preservative and as a good natural resource.

All natural organisms, such as lichens, originating from areas that are remote from the oxidation active environmental factors, could be used as natural preservatives in alternative supplementary medicine, in the form of pharmaceutical preparations prepared with appropriate solvents. The present study is an initial study that aims to guide future researches, and further advanced studies are required in the topic about pharmacological properties and bioactive compounds of lichens. The effect of lichens on human health can be favourable, opening new perspectives of investigation on their biological properties and utilization. Due to antioxidant and bioactive properties of lichens, it may promote physiological functions and contribute to the health benefit of consumers who consume lichens.

\section{References}

Aydin, E. \& Turkez, H. (2011): Effects of lichenic extracts (Bryoria capillaris, Peltigera rufescens and Xanthoria elegans) on human blood cells: a cytogenetic and biochemical study. Fresenius Environ. Bull., 20, 2992-2998.

Brisdelli, F., Perilli, M., Sellitri, D., Piovano, M., Garvarino, J.A., Nicolletti, M. Bozzi, A., Amicosante, G. \& Celenza, G. (2013): Cytotoxic activity and antioxidant capacity of purified lichen metabolites: an in vitro study. Phytother. Res., 27, 431-437. 
Bucukoglu, T.Z., Albayrak, S., Halici, M.G. \& Tay, T. (2013): Antimicrobial and antioxidant activities of extracts and lichen acids obtained from some Umbilicaria species from Central Anatolia, Turkey. J. Food Process. Pres., 37, 1103-1110.

Cernajova, I. \& Svoboda, D. (2014): Lichen compounds of common epiphytic Parmeliaceae species deter gastropods both in laboratory and in Central European temperate forests. Fungal Ecol., 11, 8-16.

EREL, O. (2004): A novel automated direct measurement method for total antioxidant capacity using a new generation, more stable ABTS radicalcation. Clin. Biochem., 37, 277-285.

Erel, O. (2005): A new automated colorimetric method for measuring total oxidant status. Clin. Biochem., 38, 1103-1111.

Hui-Yin, F., Den-En, S. \& Chi-Tang, H. (2001): Antioxidant and free radical scavenging activities of edible mushrooms. J. Food Lipids, 9, 35-46.

Luo, H., Wei, X., Yамамото, Y., Liu, Y., Wang, L., Jung, J.S., Koh, Y.J. \& Hur, J. (2010): Antioxidant activities of edible lichen Ramalina conduplicans and its free radical-scavenging constituents. Mycoscience, 51, 391-395.

Manojlovic, N.T., Vasiljevic, P.J., Maskovic, P.Z., Juskovic, M. \& Bogdanovic-Dusanovic, G. (2012): Chemical composition, antioxidant and antimicrobial activities of lichen Umbilicaria cylindrica (L.) Delise (Umbilicariaceae). Evid.-Based Compl. Alt., 2012, 8.

Moriano, C.F., Gomez-Seransillos, M.P. \& Crespo, A. (2015): Antioxidant potential of lichen species and their secondary metabolites a systematic review. Pharm. Biol., 54, 1-17.

Odabasoglu, F., Aslan, A., Cakir, A., Suleyman, H., Karagoz, Y., Bayir, Y. \& Halici, M. (2005): Antioxidant activity, reducing power and total phenolic content of some lichen species. Fitoterapia, 76, 216-219.

Paudel, B., Bhattarai, H.D., Lee, J.S., Hong, S.G., Shin, W.H. \& Yim, J.H. (2008): Antioxidant activity of polar lichens from King George Island (Antarctica). Polar Biol., 31, 605-608.

Ranković, B., Mišić, M. \& Sukdolak, S. (2007): Evaluation of antimicrobial activity of the lichens Lasallia pustulata, Parmelia sulcata, Umbilicaria crustulosa and Umbilicaria cylindrica. Microbiology, 76, 723-727

Ranković, B., Kosanić, M.M. \& STAnojković, T.P. (2011): Antioxidant, antimicrobial and anticancer activity of the lichens Cladonia furcata, Lecanora atra and Lecanora muralis. BMC Complem. Altern. Med., 11, 97.

Rankovic, B., Misic, M. \& Sukdolak, S. (2009): Antimicrobial activity of extracts of the lichens Cladonia furcata, Parmelia caperata, Parmelia pertusa, Hypogymnia physodes and Umbilicaria polyphylla. Biologia, 64, 5358.

Russo, A., Acquaviva, R., Campisi, A., Sorrenti, V., Digiacomo, C., Virgata, G., Barcellona M.L. \& Vanella, A. (2000): Bioflavonoids as antiradicals, antioxidants and DNA cleavage protectors. Cell Biol. Toxicol., 16, 9198.

Seriña, E., Arroyo, R., Manrique, E. \& Sancho, L.G. (1996): Lichen substances and their intraspecific variability within eleven Umbilicaria species in Spain. Bryologist, 99(3), 335-342.

Shimada, K., Fujikawa, K., Yahara, K. \& Nakamura, T. (1992): Antioxidative properties of xanthan on the autoxidation of soybean oil in cyclodextrin emulsion. J. Agr. Food Chem, 40, 945-948.

Sisodia, R., Geol, M., Verma, S., Rani, A. \& Dureja, P. (2013): Antibacterial and antioxidant activity of lichen species Ramalina roesleri. Nat. Prod. Res., 27, 2235-2239.

Studzińska-Sroka, E., Piotrowska, H., Kucińska, M., Murias, M. \& Bylka, W. (2016): Cytotoxic activity of physodic acid and acetone extract from Hypogymnia physodes against breast cancer cell lines. Pharm. Biol., 54(11), 2480-2485.

Subba Rao Y., Prathima, B., Hariprasad, O., Nagabhusan Reddy M. Jagadeesh, N. \& Varada Reddy, A. (2010): Synthesis, characterization and bioactivities of $\mathrm{Ni}(\mathrm{II})$ and $\mathrm{Co}(\mathrm{II})$ complexes of benzyloxybenzaldehydethiosemicarbazone. J. Chem. Pharm. Res., 2, 292-299.

Tepe, B., Degerli, S., Arslan, S., Malatyali, E. \& Sarikurkcu, C. (2011): Determination of chemical profile, antioxidant, DNA damage protection and antiamoebic activities of Teucrium polium and Stachys iberica. Fitoterapia, 82, 237-246.

Thadhani, M.V., Choudhary, M.I., Ali, S., Omar, I., Siddique, H. \& Karunaratne, V. (2011): Antioxidant activity of some lichen metabolites. Nat. Prod. Res., 25, 1827-1837.

Velmala, S., Myllys, L., Goward, T., Holien, H. \& Halonen, P. (2014): Taxonomy of Bryoria section Implexae (Parmeliaceae, Lecanoromycetes) in North America and Europe, based on chemical, morphological and molecular data. Ann. Bot. Fenn., 51, 345-371.

Zlatanović, I., Stanković, M., Jovanovic, V.S., Mitić, V., Zrnzević, I., Đordević, A. \& Stojanović, G. (2017): Biological activities of Umbilicaria crustulosa (Ach.) Frey acetone extract. J. Serb. Chem. Soc., 82(2), 141150 . 